\title{
VULNERABILITY ANALYSIS FOR THE INTEGRATED COASTAL ZONE MANAGEMENT PLAN OF THE CITY OF KAŠTELA IN CROATIA
}

\author{
M. Baučić*, M.Ivić, N. Jovanović, S. Bačić \\ Faculty of Civil Engineering, Architecture and Geodesy, University of Split, Matice hrvatske 15, 21000 Split, Croatia - \\ (martina.baucic, majda.ivic, natasa.jovanovic, samanta.bacic)@gradst.hr
}

KEY WORDS: Climate change, Coastal flooding, GIS, Integrated Coastal Zone Management, Vulnerability analysis

\begin{abstract}
:
One of the objectives of the Integrated Coastal Zone Management (ICZM) is to prevent and reduce the effects of natural hazards, particularly ones caused by climate changes. The ICZM methodologies include use of geographic information systems, from data collection and geo-analysis to dissemination of information to the public. As a part of the Interreg MED Co-evolve project cofinanced by the European regional development fund, the ICZM based action plan is being developed for the City of Kaštela in Croatia. Activities include assessing coastal vulnerability to climate change, focusing on sea flooding and storm damages and related socio-economic vulnerabilities. The paper presents development of large scale vulnerability analysis, adopted from the methodologies developed for mid and small scales. Suitability of the available data is assessed, either official or open source, and data gaps are described. The analysis's results are presented in terms of the assets exposed to coastal flooding and storms, and future improvements of analysis towards house level vulnerability analysis is envisaged.
\end{abstract}

\section{INTRODUCTION}

\subsection{Coastal zones management}

The paper presents vulnerability analysis developed for the Integrated Coastal Zone Management Plan of the City of Kaštela in Croatia. The three important issues related to the coastal areas are as follows.

Today, cca $50 \%$ of world population lives in coastal areas (ETC CCA, 2011). In EU, $19 \%$ or 86 million people live within 10 $\mathrm{km}$ from coastline. Trends are showing that number of population in coastal areas will increase in the future (ETC CCA, 2011). The second important issue is that coastal zones often have important ecological and natural values conflicting with growing demands on coastal resources imposed by human activities such as urbanisation, industry, maritime activities, agriculture, tourism etc. (ETC CCA, 2011). The third issue concerns additional pressure to coastal zones caused by climate change hazards such as coastal flooding and erosion, salt water intrusion, storm surges, loss of marine habitats and biodiversity and, still unknown, complex cascading effects (ETC CCA, 2011).

Therefore, assessing of coastal vulnerability to climate change is a necessary step for planning and managing coastal zones, particularly coastal cities. In year 2008 and 2009, the Mediterranean countries and the European union have signed "A Protocol on Integrated Coastal Zone Management (ICZM)" (UNEP/MAP/PAP, 2008). The ICZM main objective is to ensure better management and protection of coastal zones as well as dealing with environmental challenges. Based on several pilot projects, the Integrative Methodological Framework (IMF) is developed to assist in preparation of coastal management plans recommending GIS as a tool for integrated planning (UNEP/MAP/PAP et al. 2015).

\subsection{Coastal action plan for the City of Kaštela}

The Interreg Mediterranean project CO-EVOLVE defined City of Kaštela as one of the seven pilot areas for the development of coastal action plan (CAP) based on ICZM principles. The COEVOLVE project aims to promote co-evolution of human activities and natural systems in touristic coastal areas, allowing sustainable development (CO-EVOLVE project, 2019). In addition to ICZM principles, the coastal actions plans will use "Maritime and Coastal Tourism Sustainability Toolkit" developed by the CO-EVOLVE project activities. The toolkit measure tourism sustainability based on 43 ETIS CORE indicators and five sets of supplementary indicators specific for destination type and pilot areas.

The pilot area of the City of Kaštela is characterised as the coastal area with high tourist potential, where the urban development is lacking (such as undeveloped urban drainage system), causes strong pressures on natural resources and cultural heritage. Furthermore, urban areas and especially historical buildings and sea promenade are exposed to coastal erosion and flooding along the $20 \mathrm{~km}$ of coastline. Therefore, the main objective of the coastal action plan for the City of Kaštela is to promote sustainable forms of tourism-driven development with focus on coastal protection measures as a key factor for preserving coastal zone, especially historical buildings.

The expert team has undertaken a task of the coastal action plan development, consisting of experts for coastal engineering, tourism, spatial planning, oceanography, climate change, cultural heritage, biology and ecology, geoinformatics and participative approach. Experts have undertaken the comprehensive diagnostic analysis including vulnerability analysis and findings from the stakeholders. On the one hand, knowing the present situation and problems, and on the other hand, defining the anticipated future state of the area, the priorities and measures have been defined that will bring the area from the present to the future state.

This paper presents the large scale vulnerability analysis to climate change that was undertaken to support development of priorities and measures for the coastal action plan of the City of Kaštela. The second section briefly explains used methodology 
adopted from the existing ones for mid and small scales. The third section describes coastal flooding mapping, one of the main climate change hazards in the area. The fourth section describes exposed assets mapping and the results of the vulnerability analysis and the fifth section summarizes the findings and provides conclusions.

\section{METHODS FOR VULNERABILITY ANALYSIS}

\subsection{Hazard, exposure, sensitivity, vulnerability, risk}

Climate changes hazards such as coastal flooding have high impacts on costal cities, as there are large population and valuable assets exposed to the hazard. Coastal action plans are developing priorities and measures that should improve the resilience of the coastal cities on climate change hazards.

While hazards is a dangerous phenomenon or human activity that may cause loss of life, property or environmental damage, term vulnerability is a function of hazard characteristics and sensitivity of the assets exposed (Lavell, 2012). Vulnerability may refer to various aspects arising from socio-economic, environmental or physical factors (Lavell, 2012). Description of the sensitivity of the exposed asset could be extended to include its adaptive capacity. Risk considers the probability of damages or losses; it is a function of the probability of hazard and vulnerable conditions. Resilience is defined as the ability of a community exposed to hazards to resist, absorb, accommodate and recover from the hazardous events (Lavell, 2012). In this paper, climate changes hazards are explored, exposed assets sensitivity elaborated and their vulnerability analysed.

Vulnerability is a function of hazard, assets sensitivity and adoption capacity, all varying by time and depending on context such as socio-economic aspects. Therefore, vulnerability requires assessments methods that apply for different scales: spatial (large, mid, small), temporal (short, mid, long term), and management (local, regional, national) (ETC CCA, 2011).

\subsection{Coastal vulnerability methods}

In (ETC CCA, 2011), coastal vulnerability methods are classified in four categories: index-based methods, indicatorbased approach including GIS applications, GIS-based decision support systems and methods based on dynamic computer models.

Index-based methods, such as Coastal Vulnerability Index (CVI) (ETC CCA, 2011), calculate one and unit-less vulnerability index by summarizing values of the selected variables with the selected formula (such as average sum or product mean).

Indicator-based approaches use indicators representing various coastal vulnerability aspects. For the example, the Deduce Interreg project (Deduce Consortium, 2007) developed a set of 27 core indicators for sustainable coastal zone development. Climate change vulnerability is addressed by the three indicators: (i) sea level rise and extreme weather conditions (measured by number of stormy days, sea level rise and length of protected coastline); (ii) coastal erosion and accretion (measured by length of dynamic coastline, area and volume of sand nourishment and number of people living in the coastal flooding areas); and (iii) natural, human and economic assets at risk (measured by areas of protected sites and by economic values of the assets in the coastal flooding areas).
GIS-based decision support systems and methods based on dynamic computer models are characterised by development of models fitting the study area, comprehensive data sets including three dimensional models and coastal engineering applications.

The comprehensive study of the coastal vulnerability methods (ETC CCA, 2011) summarizes advantages and disadvantages of the above methods as follows: while index and indicator-based methods are simple to implement and they are appropriate for the scoping, GIS-based decision support systems and dynamic computer models provide detailed quantitative assessment and identification of adaptation measures.

Identified challenges in vulnerability assessment given by (Muller, 2011) are the following: the selection of representative variables for the study area, the definition of weights for indicators, the availability of data and the validation. Based on these challenges, the existing methods are evaluated and adopted for the vulnerability analysis presented in the paper.

\subsection{Coastal vulnerability method for the City of Kaštela}

Coastal zone of the City of Kaštela is characterized by the 20 $\mathrm{km}$ of urbanized coastline with the most valuable resources, such as sea promenade and historical buildings, located in the narrow coastline strip and already prone to coastal flooding. The three indicators developed by the Deduce Interreg project (Deduce Consortium, 2007) explained above are well representing coastal vulnerability aspects for the City of Kaštela and they are further adapted accordingly to the available data. Geographic extent of the coastal zone is small, the analysis should evaluate particular assets such as historical buildings and the results should support local management. Thus, large spatial scale is selected and adopted to the scale of available data that is 1:5.000. Mapping of the selected indicators in scale of 1:5.000 results in different tessellation of the area or in assigning values to objects representing assets. Summarizing of indicators values is not straightforward as in mid- or small-scale analysis where values are assigned to the same spatial units such as city blocks or census units. Therefore, vulnerability is expressed on two levels: detailed level for each asset object (e.g. building) and summarized per each asset type.

Dynamic computer models where not considered as feasible for the analysis because there is no available data for such detailed assessment along all $20 \mathrm{~km}$ of coastline. Such models could be used in future to provide detailed engineering solutions for the selected locations.

\section{HAZARD MAPPING}

\subsection{Coastal flooding}

The main climate change hazards and vulnerabilities in the region of Adriatic sea are: coastal flooding, coastal erosion, salt water intrusion, loss of marine habitats, ecosystems and biodiversity and socio-economic vulnerabilities (heritage, tourism, health) (ETC CCA, 2011).

In the coastal area of the City of Kaštela, main climate change hazards identified by (Margeta et al. 2019) are the following: the rise in average air and sea temperature; the decline in total rainfall; the increase number of heat waves, their duration and intensity; the concentration of precipitation in short periods and increase number of extreme precipitation events; the accelerated sea level rise in future, from today amount of about $30 \mathrm{~cm}$ per 
100 years to the predictions of $50-100 \mathrm{~cm}$ or over 1 meter till year 2100 .

The City of Kaštela is located in Kaštela bay, low coastal area is urbanised and natural hilly area is stretching inland. Today, sea level rises up to $80 \mathrm{~cm}$ during storms (Margeta et al. 2019). Extreme precipitation in short period causes extreme volumes of water in urbanised coastal zone because the drainage system is not developed and torrents are coming from hilly inland araes (Figure 1). When these two impacts coincide, all the rainwater from hilly and urban areas together with sea and underground waters are causing flooding of the lowest urbanised zone. In future, occurrences of such events will increase. Therefore, the vulnerability assessment started with mapping of the lowest coastal zones.

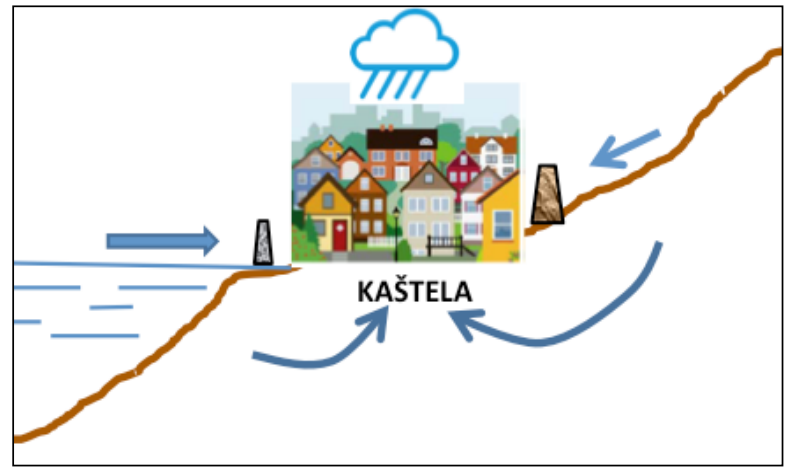

Figure 1. Rainfall, underground and sea water pressure on the coastal zone of the City of Kaštela (Margeta et al. 2019)

\subsection{DEM model and hazard zones mapping}

Free global digital elevation models (DEM) such as STRM (NASA, 2019b) or ASTER (NASA, 2019a) do not satisfy needs of the assessment. Their spatial resolution of about 30 meters is too coarse to be used for elevation mapping in the urban areas. The highest accuracy national level DEM contains raw data collected by photogrammetric mapping. Topographic features such as roads, walls and similar were mapped as $3 \mathrm{D}$ vectors from aerial photos having spatial resolution up to $30 \mathrm{~cm}$. In (Šimek at al. 2018), vertical accuracy of the Triangulated Irregular Network model (TIN) in urban areas derived from these raw data is estimated to $\pm 0.35 \mathrm{~m}$ for more then $85 \%$ of data.

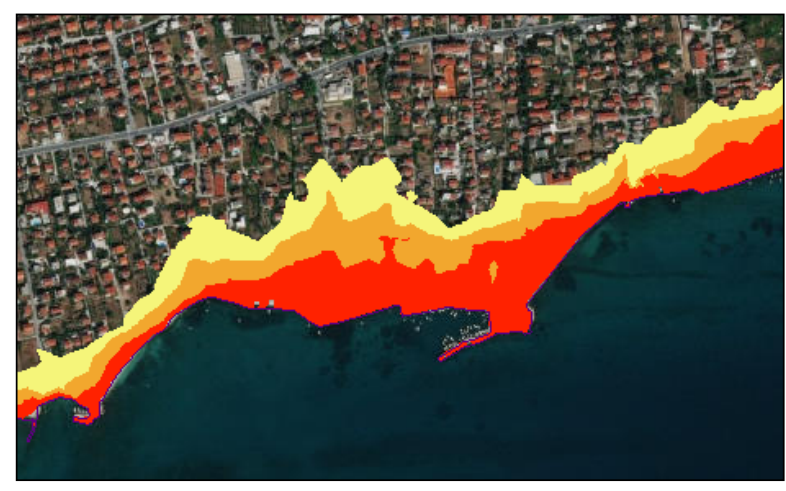

Figure 2. Hazard zone 1 (red), 2 (orange) and 3 (yellow) showing areas of 1,2 and 3 meters above sea level
Using the above described data, TIN model was created for the coastal zone of the City of Kaštela. TIN model was converted to raster model with spatial resolution of 1 meter and coastal zone was divided into 3 elevation zones representing hazard: hazard zone 1 covers areas up to $1 \mathrm{~m}$ above sea level (red colour on Figure 2), hazard zone 2 covers areas 1 to $2 \mathrm{~m}$ above sea level (orange colour on Figure 2), hazard zone 3 covers areas 2 to $3 \mathrm{~m}$ above sea level (yellow colour on Figure 2). Elevation lines of 1,2 and 3 meters above sea level extracted from TIN were overlaid over official topographic map in scale 1:5.000 for visual compering with elevation data shown on the map.

Hazard zone 1 covers 28 ha of areas already prone to coastal flooding. Distribution of hazard zones 1,2 and 3 over 7 settlements of the City of Kaštela is shown in Table 1.

\begin{tabular}{|l|l|l|l|l|}
\hline Settlement & $\begin{array}{l}\text { Hazard } \\
\text { zone 1 }\end{array}$ & $\begin{array}{l}\text { Hazard } \\
\text { zone 2 }\end{array}$ & $\begin{array}{l}\text { Hazard } \\
\text { zone 3 }\end{array}$ & $\begin{array}{l}\text { Sum (in } \\
\text { hectares) }\end{array}$ \\
\hline K. Gomilica & 3,58 & 5,13 & 5,14 & 13,86 \\
K. Kambelovac & 3,79 & 4,30 & 3,99 & 12,09 \\
Kaštel Lukšić & 2,91 & 2,51 & 2,63 & 8,04 \\
Kaštel Novi & 3,11 & 1,49 & 1,43 & 6,03 \\
Kaštel Štafilić & 6,07 & 7,08 & 11,48 & 24,62 \\
Kaštel Stari & 4,85 & 3,21 & 3,22 & 11,28 \\
Kaštel Sućurac & 3,30 & 11,45 & 19,42 & 34,17 \\
$\begin{array}{l}\text { Sum (in } \\
\text { hectares) }\end{array}$ & 27,62 & 35,17 & 47,30 & 110,09 \\
\hline
\end{tabular}

Table 1. Areas of hazard zones 1, 2 and 3 per settlement (in hectares)

\section{EXPOSED ASSETS MAPPING AND VULNERABILITY ANALYSIS}

\subsection{Exposed assets mapping}

The next step in vulnerability analysis was mapping of the assets exposed to coastal flooding. The exposure of infrastructure objects, historical heritage, as well as the exposure of buildings was mapped and analysed. Additional data expressing sensitivity of exposed assets was collected and analysed too. The input data was selected among the available official and open source data with regard to their relevance for this research.

Overall, there were eight input data layers, representing different exposed assets, which were analysed using GIS tools:

- road centerlines,

- $\quad$ sewage pump stations,

- individual objects of cultural heritage,

- urban historical zones (zones A and B),

- footprints of buildings,

- house numbers (representing housing units),

- planned land use

- type of coastline.

Important vulnerable infrastructural objects include roads, whose exposure was analysed by determining their length located in hazard zones 1, 2 and 3 (Table 2). Along the roads there is also the municipal infrastructure, what gives an additional importance to this data layer. Roads were represented by line layer of road centrelines, whose data were obtained from the Registry of streets and house numbers in the scale 1:5000. Table 2 shows that there is $7.55 \mathrm{~km}$ of roads located in the hazard zone 1 that are already endangered. 
Among the individual infrastructure objects, the sewerage pumping stations are located at the lowest elevations and near to the coastline, 9 of them are in the hazard zone 1. The sewerage pumping stations were represented by a point data layer derived from the general urban plan in scale 1:10.000 and repositioned by use of orthophoto map in scale 1:5.000. Table 2 shows the number of the sewerage pump stations located in the hazard zones.

Two sets of data related to historical and architectural heritage were used in the analysis, both obtained from the general urban plan in scale 1:10.000 and repositioned by use of ortho-photo map in scale 1:5.000. The first data set consists of polygons representing urban historical zones A and B. Zones A and B occupy a total area of 55 hectares, and the analysis showed that 12 hectares are located in the hazard zone 1 , which is $22 \%$. Areas of urban historical zones A and B located in hazard zones are shown in the Table 2.

The other data layer encompassed historical objects that are not located in the urban historical zones A and B. Table 2 shows the number of these objects located in hazard zones.

There were two sets used for the analysing the exposure of buildings in the area. The first data set contains polygons representing footprint areas of buildings. The data was obtained from the topographic map in scale of 1:5.000. The second dataset was acquired from the Registry of streets and house numbers, and it consists of points each representing one house number. Table 2 shows number of house numbers located in the hazard zones. It can be seen from the Table 2 that there are 613 house numbers that are already threatened, as they are located in hazard zone 1. Figure 3 shows building footprints and house numbers overlaid with the hazard zones.

Finally, the planned land use located in the hazard zones was analysed. According to the planned land use data obtained from the general urban plan, most land located in the hazard zone 1 belongs to mixed, built use (10.56 ha).

\begin{tabular}{|c|c|c|c|c|}
\hline Asset type - measure & $\begin{array}{l}\text { Hazard } \\
\text { zone } 1\end{array}$ & $\begin{array}{l}\text { Hazard } \\
\text { zone } 2\end{array}$ & $\begin{array}{l}\text { Hazard } \\
\text { zone } 3\end{array}$ & Sum \\
\hline Roads - length in km & 7.55 & 5.02 & 3.83 & 16.40 \\
\hline $\begin{array}{l}\text { Sewerage pumps - } \\
\text { number }\end{array}$ & 9 & 2 & 3 & 14 \\
\hline $\begin{array}{l}\text { Urban historical } \\
\text { zones A, B- area in } \\
\text { ha }\end{array}$ & 12.29 & 8.43 & 7.54 & 28.26 \\
\hline $\begin{array}{l}\text { Heritage objects - } \\
\text { number }\end{array}$ & 3 & 2 & 2 & 7 \\
\hline $\begin{array}{l}\text { Buildings footprint - } \\
\text { area in ha }\end{array}$ & 4.63 & 5.12 & 6.24 & 15.98 \\
\hline $\begin{array}{l}\text { House units - } \\
\text { number }\end{array}$ & 613 & 571 & 368 & 1552 \\
\hline
\end{tabular}

Table 2. Assets located in the hazards zones

Additional sensitivity data of roads, sewerage pumping, stations, urban historical zones and historical buildings was not collected, therefore their vulnerability depend only on their exposure. Thus, the assets located in hazard zone 1 are more vulnerable then the assets located in hazard zones 2 and 3 .

Coastline by type was mapped by visual interpretation of the national ortho-photo map in scale 1.5.000. The coastline is classified into concrete coastline, stone boulders, sand, natural and pebbles. Pie chart shown on Figure 4 shows percentage of the coastline of each type. Experts have defined stone boulders as the least vulnerable coastline type and sandy as the most vulnerable.

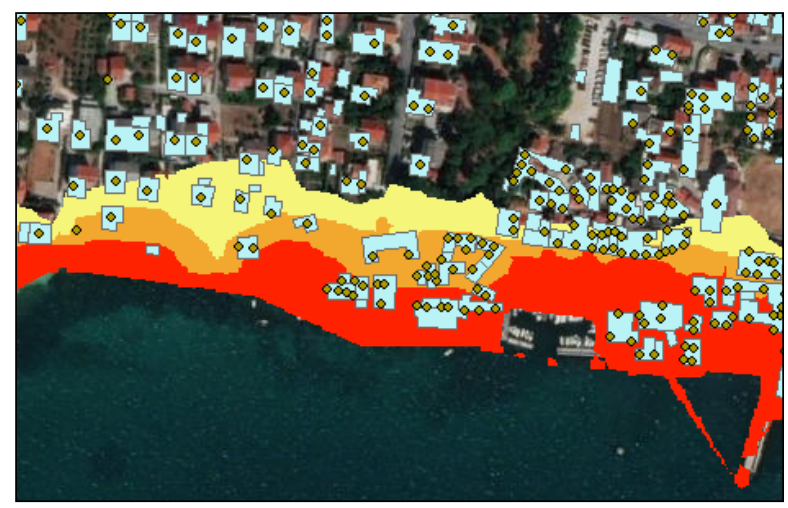

Figure 3. Building footprints and house numbers overlaid with hazard zones

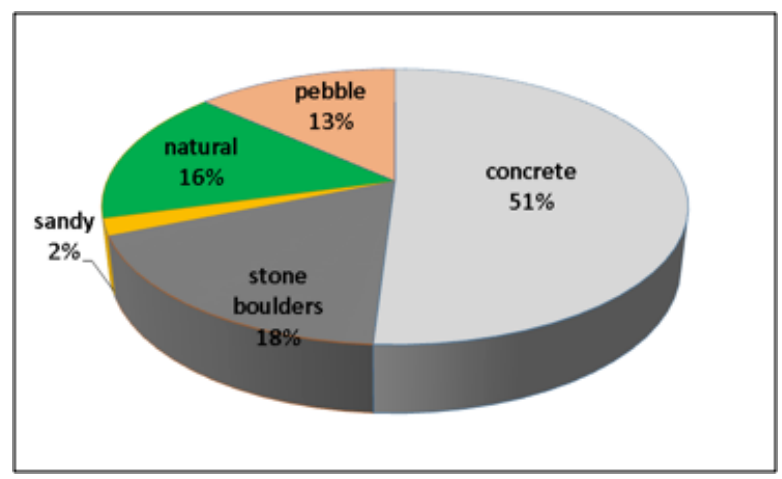

Figure 4. Percentage of coastline types (of total $23 \mathrm{~km}$ )

\subsection{Sensitivity variables for buildings}

To add sensitivity to the vulnerability assessment, additional data was collected for the buildings in urban historical zones type A by a field survey. Urban historical zones type A cover 16 hectares and there are 1088 house numbers. Additional data collected for each building floor, representing sensitivity variables, is the following: usage (residential, commercial, storage, unknown), temporal usage (abandoned, occasionally, continuously) and construction status (recently adapted, maintained, ruinous). Each building is documented by photographs too.

The field survey was conducted by use of GIS mobile application and visual inspection without interviewing the owners. Data was successfully collected for $70 \%$ of house numbers (779 of 1088) in the historical zones type A

Table 3 shows that the usage of the buildings first floor is mostly residential, Table 4 that 114 buildings are abandoned and Table 5 that 67 buildings are ruined.

\begin{tabular}{|l|l|l|l|l|}
\hline & Unknown & Storage & Commercial & Residential \\
\hline $\begin{array}{l}\text { Total } \\
\%\end{array}$ & 105 & 60 & 97 & 517 \\
\hline
\end{tabular}

Table 3. The usage of the buildings first floor 


\begin{tabular}{|l|l|l|l|}
\hline & Abandoned & Occasionally & Continuosly \\
\hline Total & 114 & 143 & 521 \\
$\%$ & $14,65 \%$ & $18,38 \%$ & $66,97 \%$ \\
\hline
\end{tabular}

Table 4. Temporal usage of the buildings

\begin{tabular}{|l|l|l|l|}
\hline & Recenty adapted & Maintained & Ruined \\
\hline Total & 112 & 599 & 67 \\
$\%$ & $14,40 \%$ & $76,99 \%$ & $8,61 \%$ \\
\hline
\end{tabular}

Table 5. Construction status of the buildings

\subsection{Vulnerability index on house level}

Combining the information of location of house number (hazard zone 1,2 or 3 ), and its sensitivity variables (usage, temporal usage and construction status), the vulnerability index of each building in urban historical zones type A was assessed. Used formula is:

$$
V_{i}=\sum v_{i}
$$

where

$$
\begin{aligned}
& V i=\text { vulnerability index on house level } \\
& v i=\text { vulnerability sub-indexes }
\end{aligned}
$$

\begin{tabular}{|c|c|c|c|c|}
\hline \begin{tabular}{|l|} 
Vulne- \\
rability \\
sub- \\
index \\
\end{tabular} & $\begin{array}{l}\text { Hazard } \\
\text { zones }\end{array}$ & Usage & $\begin{array}{l}\text { Temporal } \\
\text { usage }\end{array}$ & $\begin{array}{l}\text { Construction } \\
\text { status }\end{array}$ \\
\hline \begin{tabular}{|l}
3 \\
2 \\
1
\end{tabular} & $\begin{array}{l}1 \\
2 \\
3\end{array}$ & $\begin{array}{l}\text { residential } \\
\text { commercial } \\
\text { storage, } \\
\text { other }\end{array}$ & $\begin{array}{l}\text { abandoned } \\
\text { occasionally } \\
\text { continuously }\end{array}$ & $\begin{array}{l}\text { ruinous } \\
\text { maintained } \\
\text { recently } \\
\text { adapted }\end{array}$ \\
\hline
\end{tabular}

Assigned vulnerability sub-indexes for the hazard zones and sensitivity variables are shown in Table 6 .

Table 6. Vulnerability sub-indexes

Maximal vulnerability index is 12 and it corresponds to the abandoned and ruinous residential houses located in hazard zone 1. Minimal vulnerability index is 4 and it corresponds to the houses located in hazard zone 3, continuously used for storage or other purposes and recently adapted.

\section{CONCLUSION}

To perform large scale vulnerability analysis, large scale data should be available enabling detailed mapping of hazard and exposed assets. Topographic maps and urban plans in scale 1.5.000 still sometimes displace location of the objects due to generalization needs. For the purpose of overlaying features, any data generalisation causes wrong interpretations and objects locations should be checked prior their use and relocated if necessary. Free digital elevation models do not satisfy needs of large scale analysis due to their coarse spatial resolution. Therefore, the national data sets should be used, if available, or detailed data should be acquired by surveying such as laser scanning.

Assigning vulnerability index in case of large scale analysis brings a problem of non-uniform tessellation by the vulnerability variables. One solution is to assign vulnerability index to each object, such as buildings. In the vulnerability analysis for the City of Kaštela, a vulnerability index was assigned to each house number. House numbers, as locations holding vulnerability information, could be used for integrating valuable census data that is collected on the house numbers level. Municipality databases are also storing various data with the reference to house numbers, and that data could be integrated too. Therefore, future extension of the vulnerability analysis presented in the paper could be in extending vulnerability variables with the socio-economic description of the inhabitants in the hazard zones.

\section{REFERENCES}

ETC CCA, 2011. Methods for assessing coastal vulnerability to climate change. European Topic Centre on Climate Change Impacts, Vulnerability and Adaptation, Bologna, Italy.

CO-EVOLVE Interreg med project, 2019. https://coevolve.interreg-med.eu (20 July 2019).

Deduce Consortium, $2007 . \quad$ https://www.mspplatform.eu/practices/assessment-model-sustainabledevelopment-european-coastal-zones (20 July 2019).

Lavell, A., M. Oppenheimer, C. Diop, J. Hess, R. Lempert, J. Li, R. Muir-Wood, and S. Myeong, 2012. Climate change: new dimensions in disaster risk, exposure, vulnerability, and resilience. In: Managing the Risks of Extreme Events and Disasters to Advance Climate Change Adaptation [Field, C.B., V. Barros, T.F. Stocker, D. Qin, D.J. Dokken, K.L. Ebi, M.D. Mastrandrea, K.J. Mach, G.-K. Plattner, S.K. Allen, M. Tignor, and P.M. Midgley (eds.)]. A Special Report of Working Groups I and II of the Intergovernmental Panel on Climate Change (IPCC). Cambridge University Press, Cambridge, UK, and New York, NY, USA, pp. 25-64.

Margeta, J., Vilibić, I., Jakl, Z., Marasović, K., Petrić, L., Mandić, A., Grgić, A., Bartulović, H., Baučić, M., 2019. Draft version: Coastal Action Plan for the City of Kaštela. JU RERA, Split, Croatia.

Miller, A., Reiter, J., Weiland, U., 2011. Assessment of urban vulnerability towards floods using an indicator-based approach - a case study for Santiago de Chile. Nat. Hazards Earth Syst. Sci., 11, 2107-2123, doi:10.5194/nhess-11-2107-2011.

NASA, 2019a. ASTER digital elevation model https://asterweb.jpl.nasa.gov/gdem.asp (20 July 2019).

NASA, 2019a. SRTM digital elevation model https://www2.jpl.nasa.gov/srtm/ (20 July 2019).

UNEP/MAP/PAP, 2008. Protocol on Integrated Coastal Zone Management in the Mediterranean. Priority Actions Programme, Split, Croatia.

UNEP/MAP-PAP/RAC, GWP-Med and UNESCO-IHP. 2015. An Integrative Methodological Framework (IMF) for coastal, river basin and aquifer management. M. Scoullos (ed.). Med Partnership, Split, Croatia.

Šimek, K., Medak, D., Medved, I., 2018. Analiza visinske točnosti službenoga vektorskoga digitalnoga modela reljefa Republike Hrvatske dobivenog fotogrametrijskom restitucijom. Geodetski list 2018, 3, 217-230. Zagreb, Croatia. 